\title{
準リアルタイム衛星画像によるロ永良部島噴火 災害の即応調査と周辺環境への影響評価
}

\author{
羽柴 秀樹1・園部 雅史2 \\ 1正会員 日本大学准教授 理工学部土木工学科（†101-8308 東京都千代田区神田駿河台1-8-14） \\ E-mail:hashiba3@civil.cst.nihon-u.ac.jp \\ 2正会員 (株)パスコ 衛星事業部（干164-0001東京都中野区中野4-10-1 中野セントラルパークイースト3F） \\ E-mail:meabso6634@pasco.co.jp
}

\begin{abstract}
2015年5月29日の鹿児島県・ 口永良部島にて大規模な噴火が発生した。この噴火によって火砕流が発生 し海岸域まで到達した。本研究では, 今回の大規模噴火の前後に観測され準リアルタイムに配信された Landsat-8/OLIセンサによるマルチスペクトル衛星観測情報とASTER/Global DEM情報を利用し, 噴火によ る火砕流の広がりと周辺土地被覆の被災状況の画像判読と3次元表示から詳細な調査を行った. また正規 化植生指標值の解析によって, 周辺森林域の被災状況の分析を試みた。これらの調査検討から, 噴火によ る自然災害評価に対する準リアルタイムリモートセンシングによる画像情報の有効性について考察した。
\end{abstract}

Key Words : Landsat-8/OLI, GDEM, disaster, eruption, interpretation, NDVI, Remote Sensing

\section{1. はじめに}

2015年5月29日に鹿児島県口永良部島において大規模 な噴火が発生した．大規模噴火であったことに加え，火 砕流が発生したことがこれまでに報告されている12)。こ のような大規模な噴火現象に伴う対応として防災へリに よる緊急撮影が行われる。しかし，悪天候で飛行不可の 場合や噴煙等により，火口付近に近づけず調査が困難な 場合がある.このような背景から，これまでに衛星リモ ートセンシングによる火山活動の調査や監視が数多く実 施されてきている3 ${ }^{3 \sim 5)}$. 被災状況の調査と周辺土地被覆 の継続的な環境モニタリングに対して，周期的な観測特 性を有する衛星リモートセンシングは有効な観測評価手 段の一つである. 最近では天候や噴煙の影響を受けるこ とが少ない合成開ロレーダ（SAR）衛星による観測が数 多く実施されてきている为。しかしながら，火砕流等の 発生に伴う火山周辺の土地被覆や森林環境一の影響など を詳細に把握するためには，光学式センサでのマルチス ペクトル画像情報の特性が大きく貢献すると考えられる 8),9. また，近年では中分解能クラスの光学式センサによ る観測情報は, 観測後に準リアルタイムでの入手が容易 となり, 被災状況の迅速な把握と評価が可能と考えられ る. 本研究では観測後, 準リアルタイムに観測データを 入手可能なLandsat-8衛星画像を用いる. 本衛星は16日周 期で同一範囲を観測するため，即応フェーズでの被害の
概要調査や復旧・復興フェーズでの定期的且つ時系列な モニタリングを捉えることが可能であり，防災分野の利 用に期待できる. そこで，口永良部島の大規模噴火の前 後に観測されたLandsat-8衛星によるOLI(Operational Land Imager)センサで観測されたマルチスペクトル画像情報と ASTER Global DEM(ASTER/GDEM)情報を利用し，噴火に よる火砕流の広がりと周辺土地被覆の変化を画像判読と 3次元表示による地形モデルから調査した。 また植生指 標值の解析によって, 火口周辺の被害域の判読調査や噴 火による植生域の焼失した範囲の抽出を試みた。 これら の観測後に準リアルタイムで入手可能な災害前後の Landsat-8衛星画像を用いた簡易的な被害域の判読調查と 正規化植生指標值の差分による植生被害域の抽出の $2 つ$ の被害域の把握手法の検討結果から即応フェーズでの概 要調查に対する適用性を考察した.

\section{2. 方法}

\section{（1）使用衛星データ}

ここでは，噴火前後に観測されたLandsat-8/OLIデータ を使用した．観測日は噴火前が2015年5月5日，噴火後が 2015年6月6日である. OLIセンサは8つのバンド帯のマル チスペクトル画像を分解能 $30 \mathrm{~m} \times 30 \mathrm{~m}$ で，パンクロマテ イック画像を分解能 $15 \mathrm{~m} \times 15 \mathrm{~m}$ で観測している．これら の観測データはUSGS（米国地質調査所）で整備されて 
いる準リアルタイム衛星データベースのEarthexplolerから 入手した．また標高データは分解能 $30 \mathrm{~m}$ で高さ精度が $7 \mathrm{~m}$ 〜14mのASTER/GDEMを使用した．なお，本データは地 形改変前に取得した画像で作成された標高データである ため，噴火による地形改変を反映されていないデータで ある。しかしながら，火山噴火予知連拡大幹事会の気象 研究所の報告10)によると噴火前後の陸域観測技術衛星 2 号（ALOS-2）を用いた干渉解析結果において衛星視線 方向で10 cm以下の変位であることが報告されており, 標 高データの精度を超えない変位であるため, 噴火による 地形改変の影響は無視した。

\section{(2) 調査領域}

噴火した島東部域の新岳を中心とした $5 \mathrm{~km} \times 5 \mathrm{~km}$ の範囲 を選定した（図-1）。

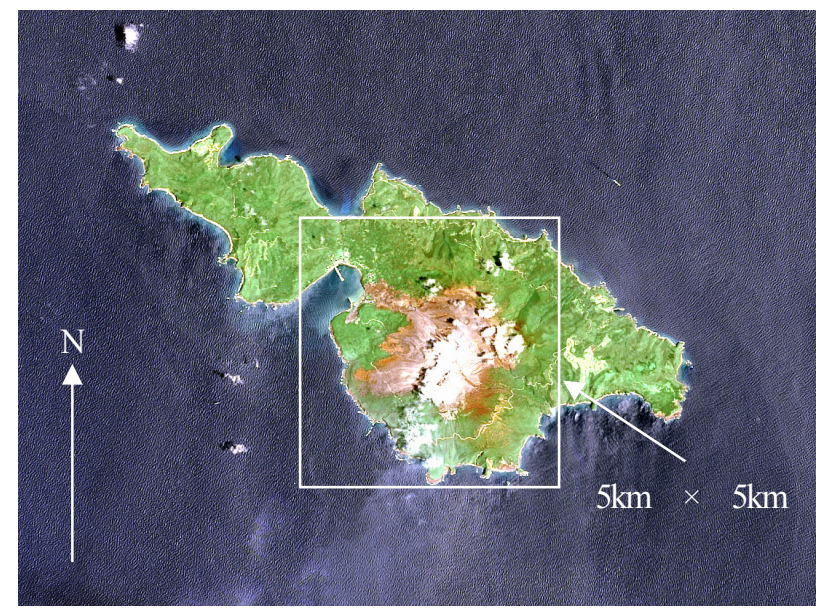

図-1 調査対象領域

\section{(3) 衛星画像データのパンシャープンと画像判読}

Landsat-8/OLIセンサによる可視光域のマルチスペクト ル画像データの有する地上分解能は $30 \mathrm{~m} \times 30 \mathrm{~m}$ である. 噴火の影響をよりわかりやすく詳細に判読調査するため に，同時観測されている地上分解能 $15 \mathrm{~m} \times 15 \mathrm{~m}$ のパンク ロマティック画像データを用いて，パンクロマティック の観測波長帯域に対応したR，G，Bの可視光域マルチス ペクトル画像データをパンシャープンした．ここでの処 理手法としては，一般的に広く利用されているZhang Y. によって検討されている手法11)を使用した．なお，パン シャープン画像の作成にあたり，観測波長帯域のBの一 部が欠落するが，本研究においてパンシャープン画像は ピクセル值を使用するものではなく, 判読調查のみの使 用のため無視するものとする。 これによって得られた噴 火前と噴火後のパンシャープン画像から, 噴火後の火口 周辺および火砕流が発生したとみられる周辺域の土地被 覆変化の状況を画像判読によって調査した.

（4）パンシャープン画像の3次元表示による火砕流通過 領域の調査
得られたパンシャープン画像とASTER/GDEMデータ を合わせて利用し，噴火前後の火口周辺域の3次元画像 を作成した. 処理には市販されている3次元モデリング ソフトウェアを使用し，種々の角度から鳥瞰図を作成で きるようにした，これにより，火砕流の通過域の地形的 な特性を分析した. 判読調查の比較対象として噴火後の 2015年6月4日に緊急撮影された空中写真 ${ }^{14)}$ 参照した.

\section{(5) 画像データの地表面反射率への変換と正規化植生 指標値による分析}

Landsat-8/OLIセンサによるマルチスペクトル画像デー タのDN值について大気補正処理を行い, 地表面反射率 に変換した. 大気補正処理手法はRichter R.,et al.によって

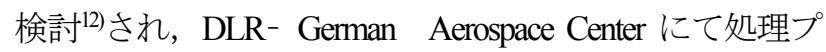
ログラムが提案されているATCOR アルゴリズムを使用 した. 地表面反射率( $(\rho)$ に変換後の画像データに対して, 以下の式(1)による方法で正規化植生指標值を噴火前後 のそれぞれの画像データで算出し，その変化過程を調査 した.

$$
\mathrm{NDVI}=\left(\rho_{\text {Band5 }}-\rho_{\text {Band } 14)}\right) /\left(\rho_{\text {Band }}+\rho_{\text {Banda }}\right)
$$

なお，Band4は可視光赤波長帯域, Band5は近赤外波長 帯域の観測バンドを示す。得られたNDVI值は-1から+1 の值となり+1に近づくほど植生活性度が高い傾向を示す。

\section{（6）正規化植生指標值の差分による被害域の抽出}

火砕流による森林への影響を詳細に把握するために, 継続的な植生モニタリング手法として以下の(2)式を用 いた．ピクセルごとに算出した差分画像データから非被 害域と被害域を区分する間值を決定することにより，2 值化画像を作成した。閾值の妥当性の確認のため, 噴火 前後のLandsat-8パンシャープン画像から目視判読により 植生の被害域を作成し抽出率を算出した.

$$
\mathrm{D}=\mathrm{NDVI}_{\text {affer }}-\mathrm{NDVI}_{\mathrm{befue}}
$$

なお，噴火前の高い正規化植生指標值の箇所が噴火後 の火砕流等からの被害により, 正規化植生指標值が減少 するため被害域は正規化植生指標值の差は負の值をとる.

\section{3. 噴火前後の状況変化の調査 - 分析結果}

\section{（1）噴火前後のパンシャープン画像および3次元画像の 判読結果}

噴火前後のパンシャープン画像を図-2,3に示す．図に 示されるように，噴火後において樹木の焼失領域と考え られる茶褐色の領域が大きく拡大していることが認めら 
れた．また，火口を中心として噴石等の拡散による裸地， 砂地の色彩を呈した領域がさらに拡大している傾向が認 められた。領域A（図-4,5）において森林域が緑色から 幅500mに渡って茶褐色の発色に変化していることから， 今回発生した火砕流によって周辺の森林が全焼失もしく は半焼失している状況が認められた．特に3次元表示

（図-8,9）では，地形の谷線の中心に集まるようにして 森林が焼失している傾向がみられる。 また, 領域B（図 -6,7）においては，地形の起伏は大きくなく，火砕流や 噴石等が海岸線の方向にむけて拡散するように広がって おり，火砕流の影響が海域まで届いていないことが認め られた。 このように，地形条件と火砕流の進行方向に関 連性が認められた。同様な傾向は空中写真情報（図一 10）からも判断できる.

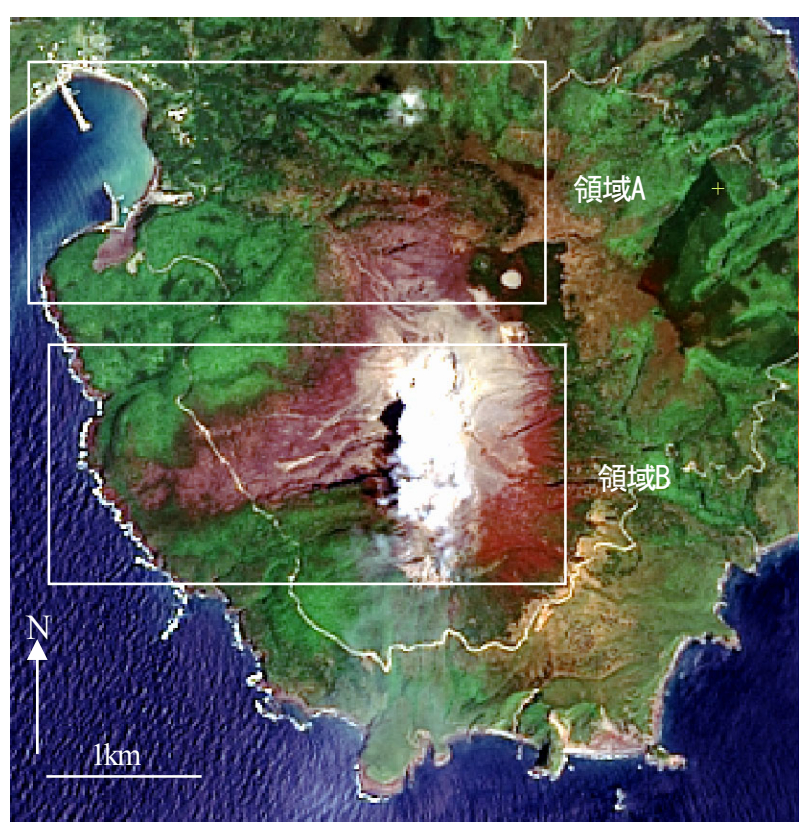

図-2 噴火前（2015年5月5日観測）のLandsat-8/OLによる パンシャープン画像（TrueColor表示）
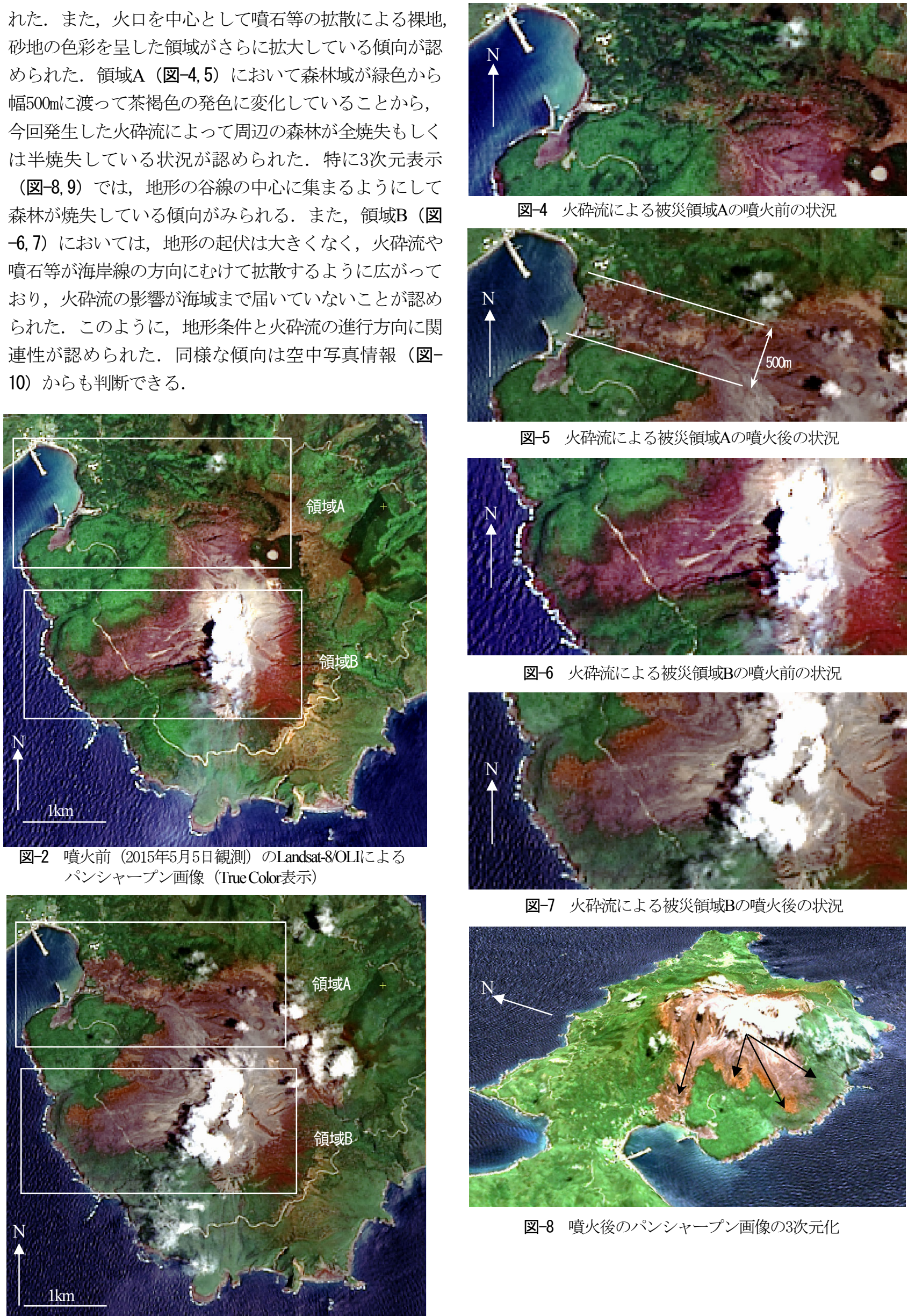

図-4火砕流による被災領域Aの噴火前の状況

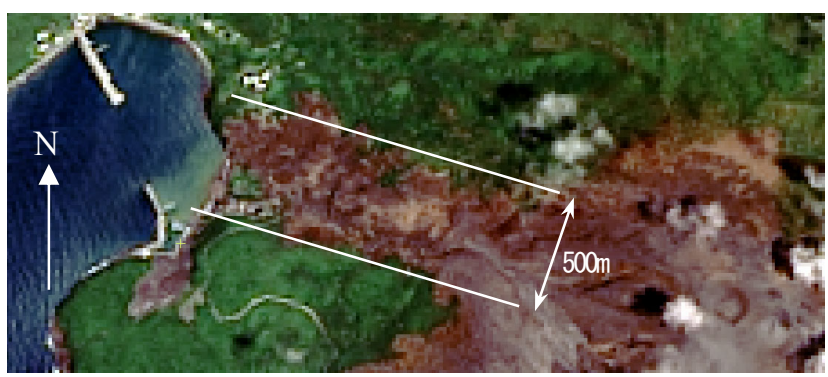

図-5 火砕流による被災領域Aの噴火後の状況

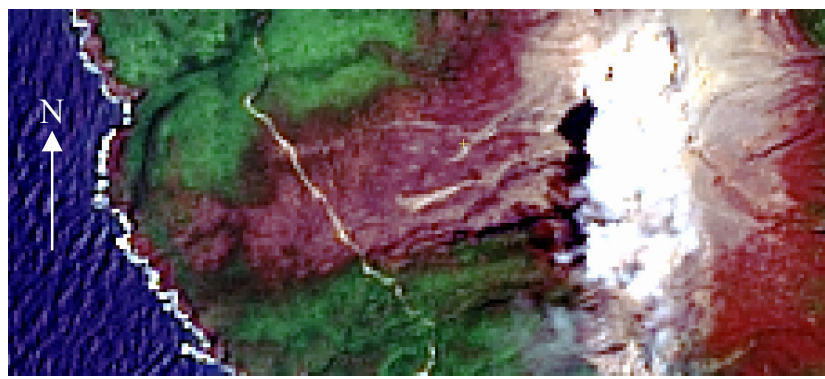

図-6 火砕流による被災領域Bの噴火前の状況

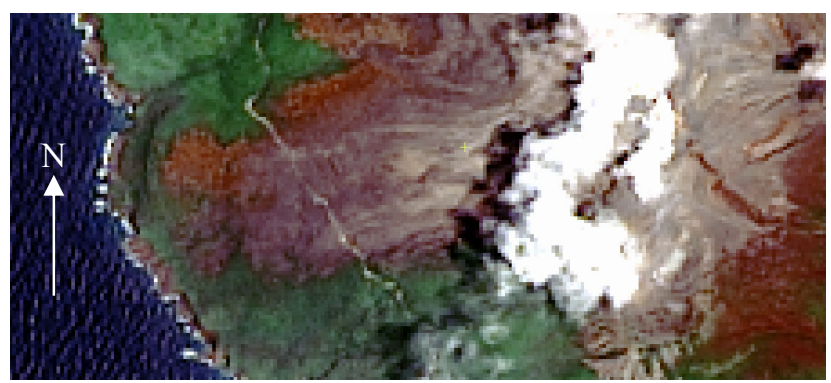

図-7 火砕流による被災領域Bの噴火後の状況

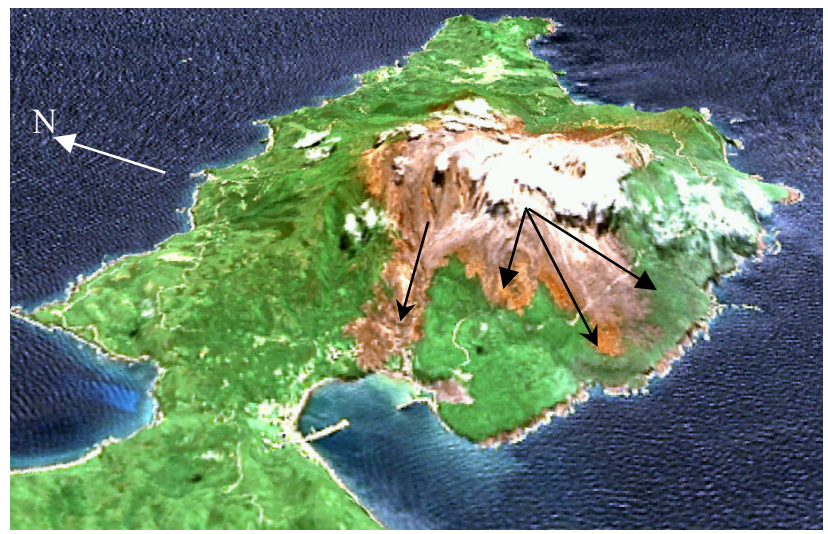

図-8＼cjkstart噴火後のパンシャープン画像の3次元化

図-3 噴火後（2015年6月6日観測）のLandsat-8/OLIによる パンシャープン画像（TrueColor表示） 


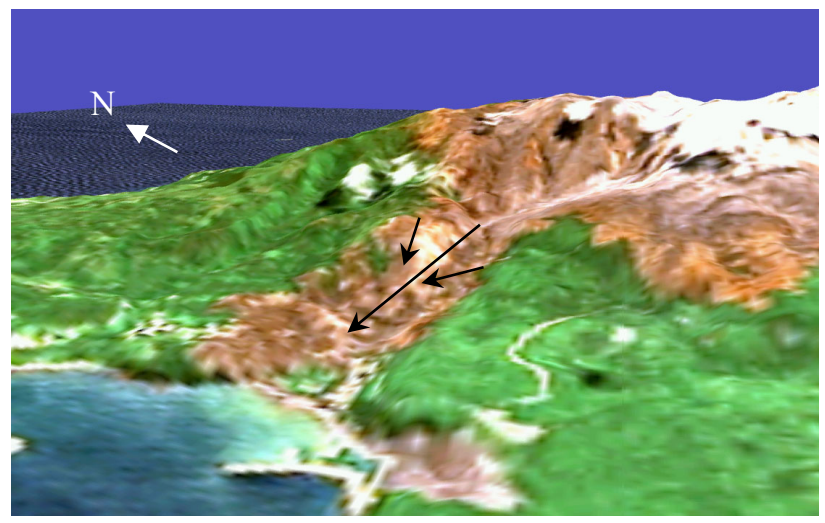

図-9 口永良部漁港周辺の被災状況の3次元画像の拡大

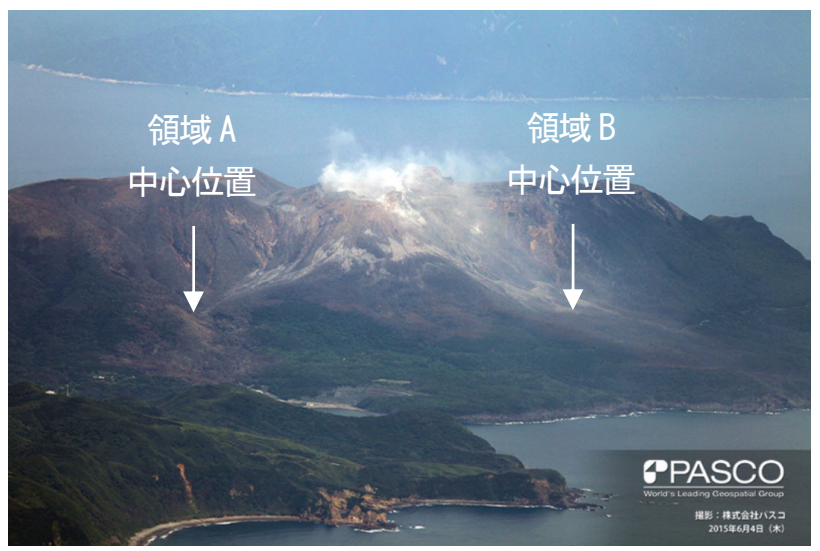

図-10 口永良部漁港周辺の空中写真 (写真提供 : 株式会社パスコ)

\section{（2）噴火前後の正規化植生指標値の変化傾向}

噴火前後における対象領域全域のNDVI值の分布傾向 を図-11〜13に示す．なお，ここで海面域はマスク処理 によって統計量算定および面的表示から除外した。噴火 前に植生の活性度が高い箇所に対し，火砕流や降灰を主 とした噴火現象により，植生が劣化し，活性度が低下し たため，高いNDVI值の統計量の減少傾向が確認できた. これは噴火後のNDVI画像（図-13）の橙色に近い範囲で ある. また，火砕流流下等による直接植生が焼失したこ とによる低いNDVI值の増加傾向が示された。 これは噴 火前で裸地の範囲を除く噴火後のNDVI画像（図-13）で 緑色に近い範囲である．なお，火口西側の被雲箇所が NDVI值の統計量に影響を与えていると考えられる，面 的にも画像判読で得られた結果と同様な方向性で低い NDVI值の領域が海岸線方向に拡大している傾向が認め られた。これにより，火砕流による領域Aおよび領域B などの海岸線に近傍における森林部が焼失し急減な NDVI值の変化につながったと考えられる.この結果と, 空中写真判読から得られた結果 ${ }^{13)}$ と比較し同様の傾向が 示されていることを確認した。 このように植生の活性度 を示すと考えられる植生指標值が，火口周辺の被害域の 判読調査や噴火による植生の焼失や劣化範囲の抽出によ る被害域の傾向把握が可能であることが考察された。

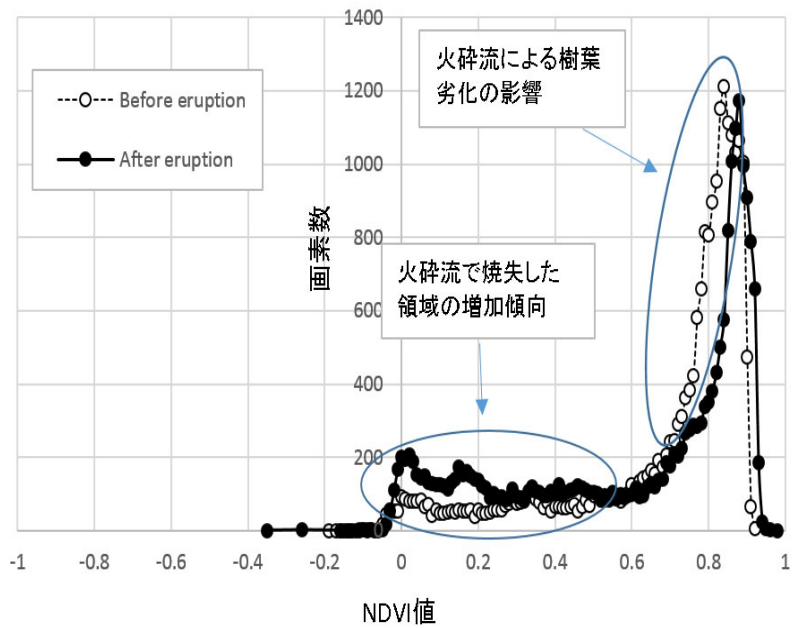

図-11 調査対象領域内の噴火前後のNDVI值

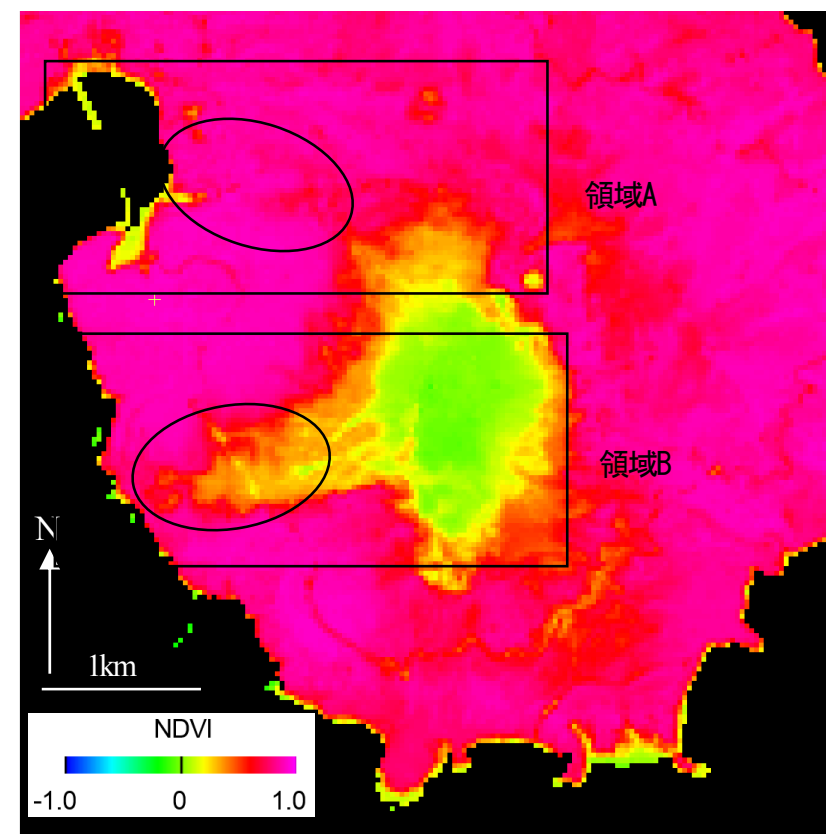

図-12 噴火前のNDVI值の分布状況

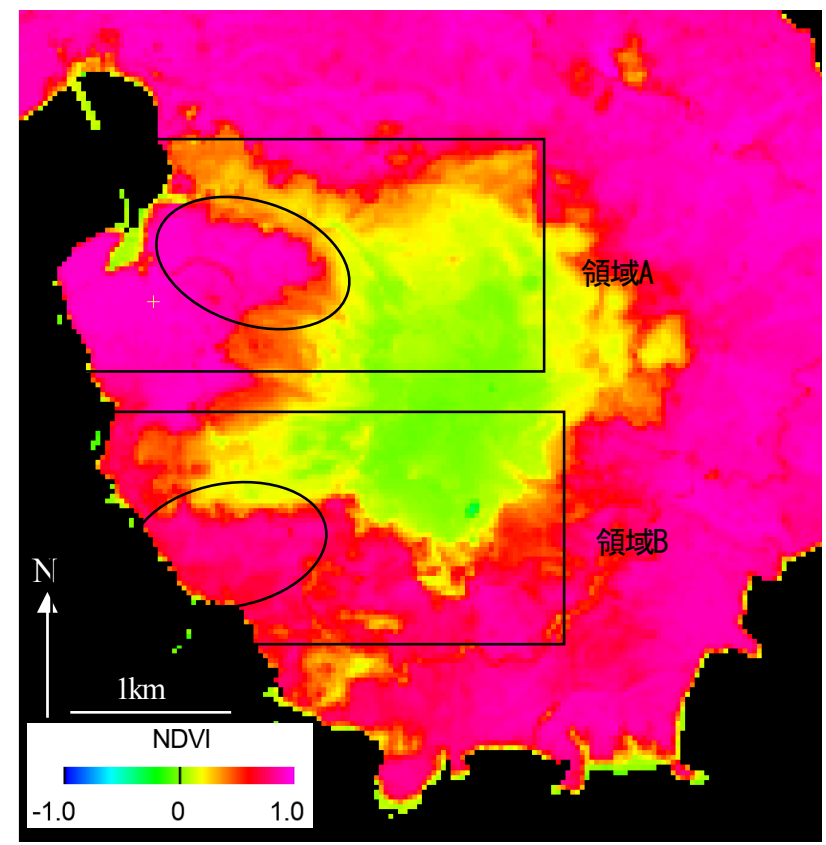

図-13 噴火後のNDVI值の分布状況 


\section{(3) 正規化植生指標値の差分による被害域の抽出結果}

噴火前後の正規化植生指標值を比較し，式(2)による 算出結果から表示された差分の分布と，そこから抽出さ れた被害域の面的な分布状況を図-14 15に示寸．なお， ここでは即応的な調查として噴煙や雲の除去は実施しな いこととした．D值が 0 付近で単峰性の正規分布の形状 となることから，噴火前後画像で季節変化や観測状況に よる変化がほぼ受けていない領域や噴煙や被雲の影響を 受けてない領域が顕著であることがわかる，なお，D值 が負の值の範囲においてはD值が小さくなるほじ，統計 量は減少していることがわかる，この時，統計量には噴 火による変動に加え，季節や被雲，さらには観測状況に よる変動が混在する．このため，本手法はこれらの影響 がなるべく少ない二時期のデータが必要である.このよ うな理由から，植生が顕著に減少したことを示寸閾值を ヒストグラムの分布特徵から簡易に決定寸ることは困難 であることを考察した，そこでヒストグラムの平均值 $(\mu)$ と標準偏差 $(\sigma)$ から段階的に閾值を設定し被害域を抽 出した. ここでは，Landsat-8パンシャープン画像の目視 判読と比較し，同様な被害域の分布形状が抽出され，か つ抽出率の高い(1)の閾值を決定した。この結果から，被 害域の抽出結果から噴火前の高いNDVI值の箇所が噴火 後の火砕流等からの被害により NDVI值が減少寸る箇所 が推定できることを確認した．特に火口西側においては 火砕流の流出によって周辺の森林が全焼失もしくは半焼 失した箇所の形状がほぼ正しく抽出されていることが確 認できた.これにより火砕流の通過域も画像から確認で きる．ただし，火口南側と西側の森林被覆において噴火 前後に噴煙あるいは雲が存在する場合は，差分が大きく なる場合があり、過抽出されることが認められた．雲の 除去等にはマスク処理による評価からの除外や同観測時 期のアーカイブデータを用いて補正する方法が知られて いる. 一方で災害時の即応フェーズでは迅速かつ的確な 初動対応の確立に被害状況の早期把握が求められる。 こ れに対し，本手法は大凡の被害域が抽出されていること や簡易的であることから即応フェーズでの被害域の概要 調查に有効であると考えられる.この結果と噴火後に撮 影された無人航空機(UAV)による空中写真との写真判読 結果 ${ }^{14)}$ と比較し，火砕流や熱風による森林の焼失と同様 の傾向が示されていることを確認した.

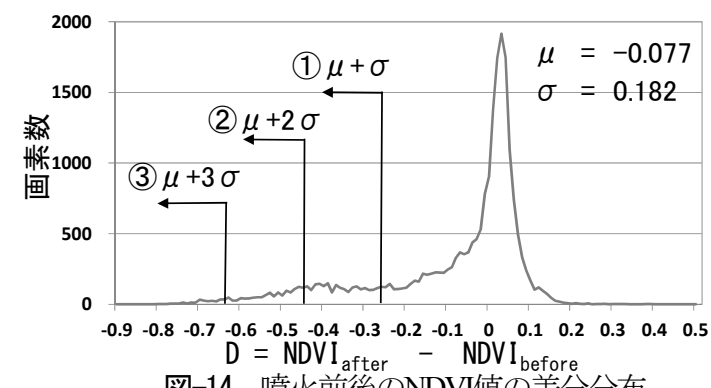

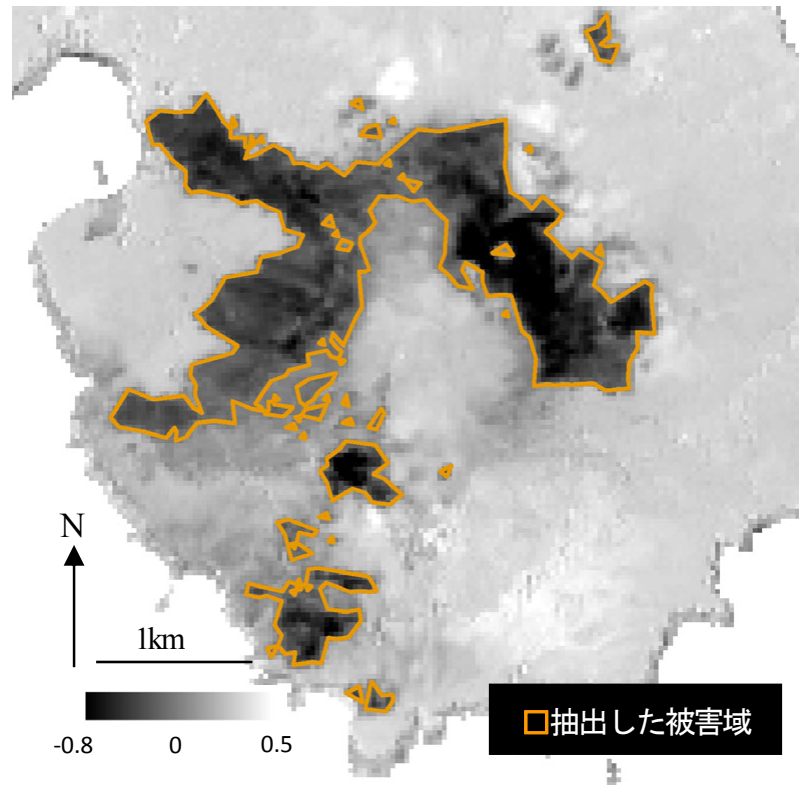

図-15 NDVI值の差分画像と被害域の抽出

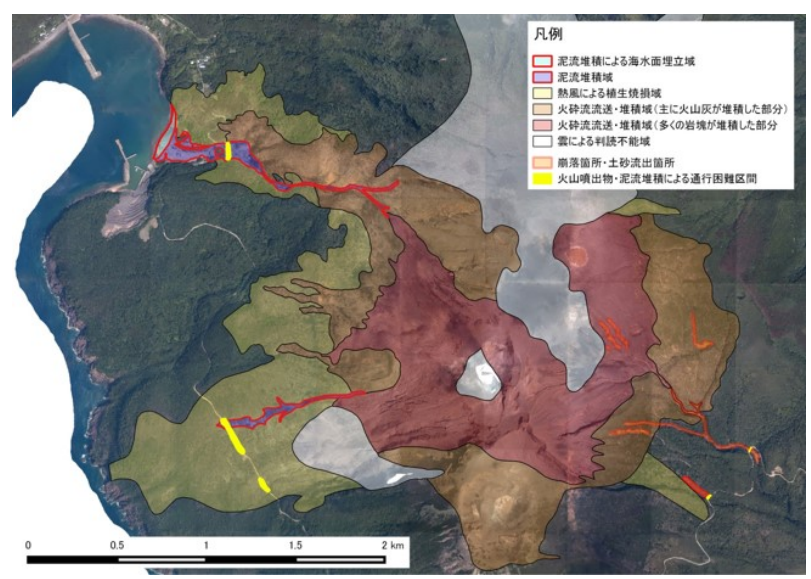

図-16 無人航空機 $(U A V)$ にる口永良部島の空中写真 の判読結果 (写真提供 : 国土地理院)

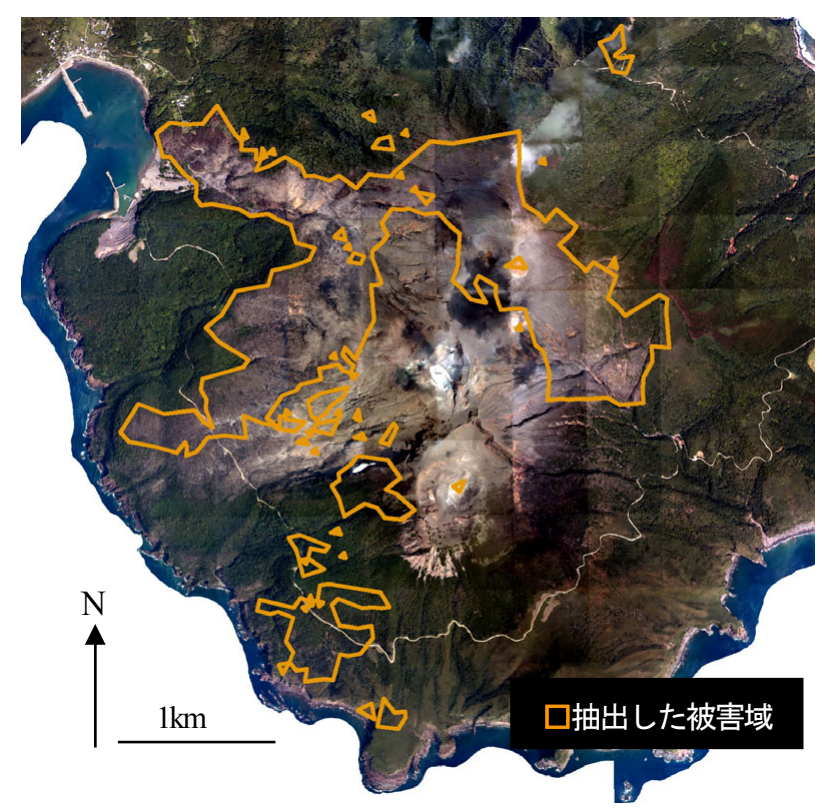

図-17 無人航空機 $(U A V)$ にる口永良部島の空中写真 (写真提供 : 国土地理院) 


\section{4. 精度検証}

\section{(1) 方法}

噴火前後の正規化植生指標值の差分を用いた植生の被 害域抽出手法の閾值の妥当性と抽出範囲の精度検証のた め, 植生の被害域の検証基準を噴火前後のLandsat-8パン シャープン画像の判読結果から作成し, 抽出率を求めた 検証デー夕は噴火後画像において茶褐色の裸地範囲をデ ジタイズし（図-18），該当範囲において噴火前画像で の裸地範囲をデジタイズした（図-19）。さらに噴火後 の裸地範囲から噴火前の裸地範囲を減じることで噴火に よる植生の被害域を作成した（図-20）。得られた目視 判読による植生被害域と正規化植生指標值の差分を用い た植生の被害域の面積を比較し，抽出率を算出した。さ らに，正規化植生指標值の差分手法により得られた被害 域と国土地理院によって公表されたUAVの空中写真判 読結果を比較した。なお，UAVによる空中写真の判読 結果は検証範囲において噴火による影響があった範囲を デジタイズし，検証基準として設定した。また，精度検 証の範囲はLandsat-8衛星画像や参照するUAV空中写真の 火口南方面に噴煙や被雲や雲影の影響が認められるため, 火砕流が流下し，植生の被害が顕著な火口北東側とした。

\section{（2）目視判読結果と正規化植生指標値の差分による抽 出結果の比較}

Landast-8衛星パンシャープン画像による植生の被害域 の目視判読結果と噴火前後の正規化植生指標值の差分に よる植生の被害域を抽出した結果を図-21, 表-1に示す. 目視判読結果の $91 \%$ の面積を抽出できた結果から本手法 で設定した閾值で妥当性が検証された。

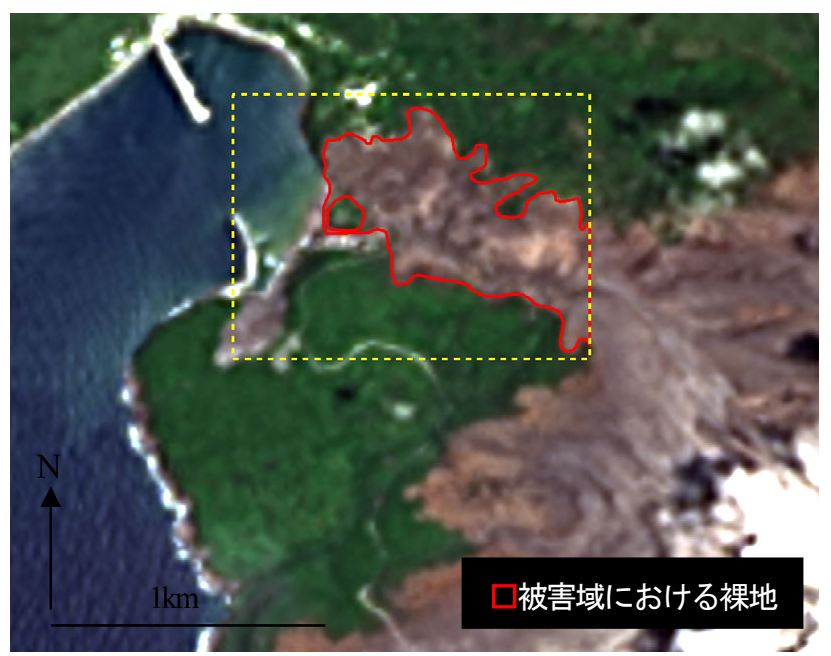

図-18＼cjkstart噴火後画像における裸地の目視判読結果

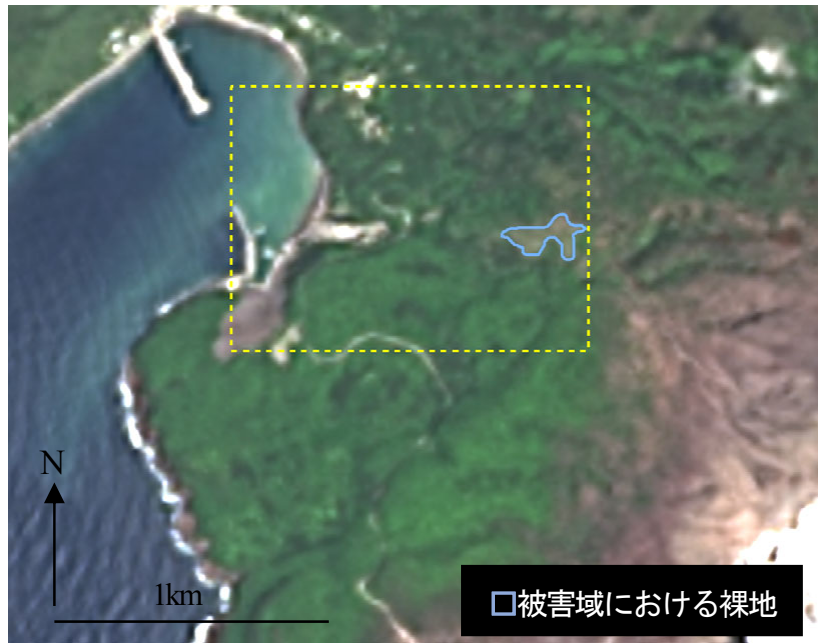

図-19＼cjkstart噴火前画像における裸地の目視判読結果

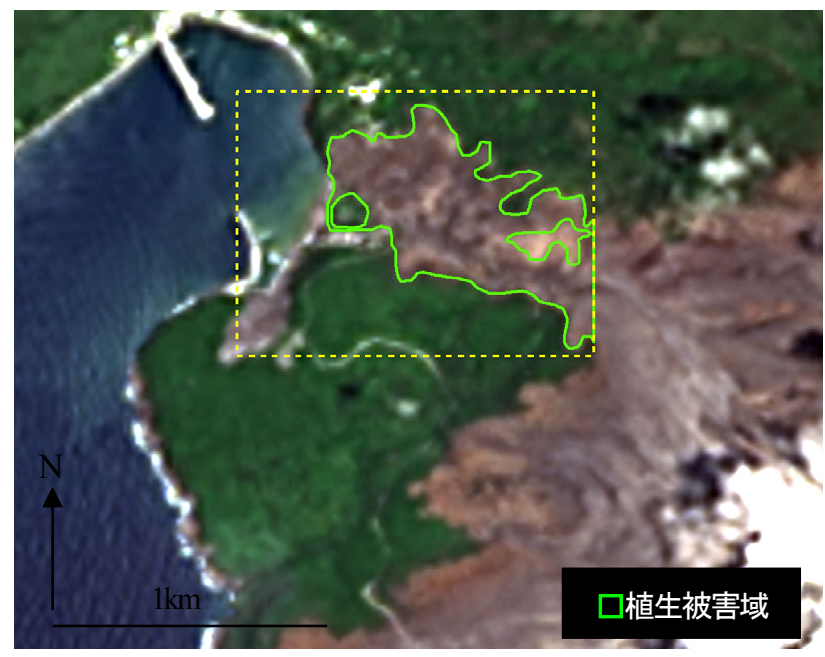

図-20 植生被害域の目視判読結果

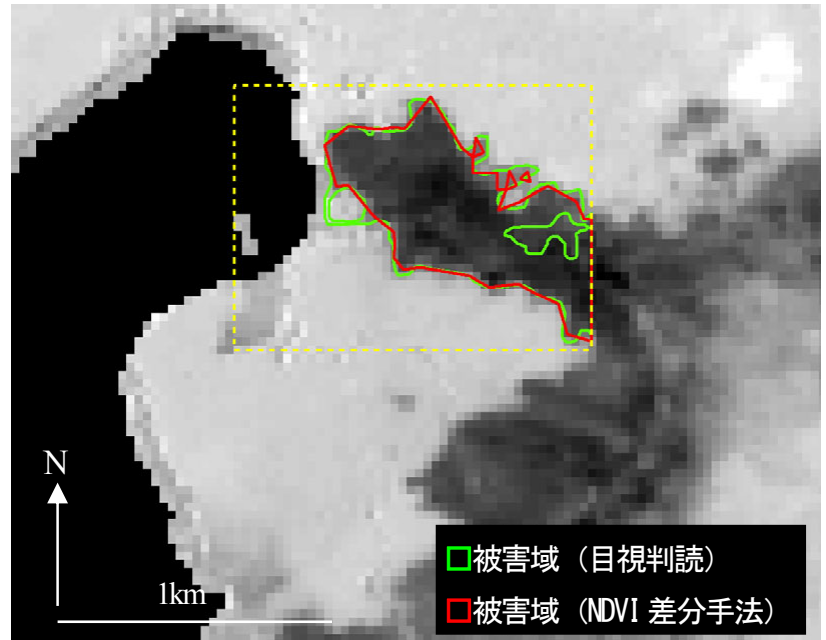

図-21 Landast-8画像の植生被害目視判読結果と噴火前後の NDVI值の差分抽出結果

表-1 Landast-8画像の目視判読結果と正規化植生指標値 の差分による抽出面積の比較

\begin{tabular}{|ccc|}
\hline $\begin{array}{c}\text { Landsat-8 } \\
\text { 目視判読 }\left(\mathrm{m}^{2}\right)\end{array}$ & $\begin{array}{c}\text { 正規化植生指 } \\
\text { 標值差分抽出 }\left(\mathrm{m}^{2}\right)\end{array}$ & $\begin{array}{c}\text { 抽出(合致) } \\
\text { 面積 }\left(\mathrm{m}^{2}\right)\end{array}$ \\
\hline 390850.5 & 387734.5 & $356943.4(91 \%)$ \\
\hline
\end{tabular}


（3）UAVの空中写真視判読結果と正規化植生指標値の 差分による抽出結果の比較

国土地理院によって判読調査されたUAVによる空中 写真を用いた被害域の公表結果と噴火前後の正規化植生 指標值の差分による植生の被害域を抽出した結果の比較 を図-22，表-2に示す．UAVの空中写真判読結果の $76 \%$ の面積を抽出できていることが示された.この結果から 今回の抽出方法により大凡の植生被害域を抽出できるこ とがわかった. このように噴火前後の植生植生指標值の 差分を算出することにより, 火砕流による被害域の概要 を即応的に抽出できる可能性が示された.

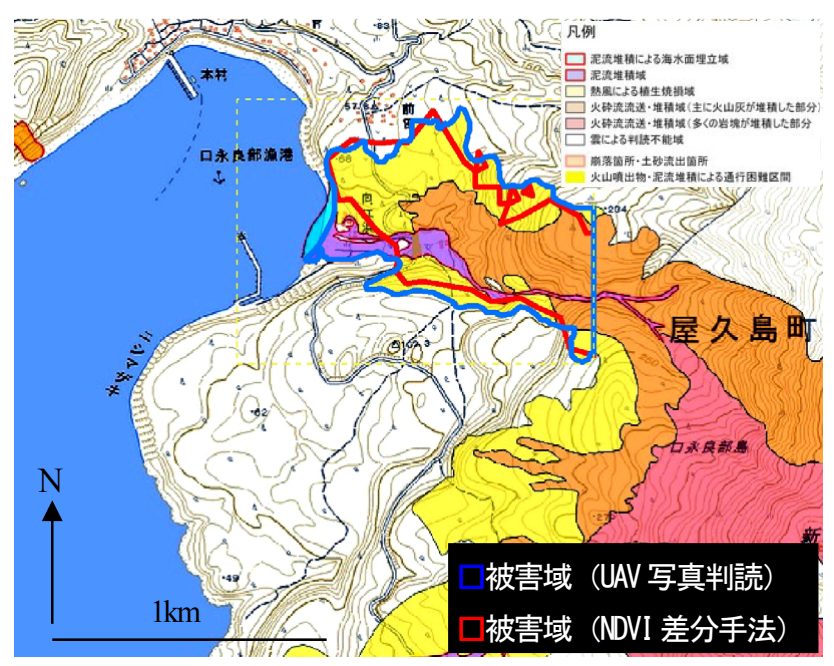

図-22 無人航空機(UAV)による口永良部島の空中写真の 判読結果と噴火前後のNDVI值の差分抽出結果 (判読図提供 : 国土地理院)

表-2 UAVによる空中写真の判読結果と正規化植生指標 の差分による抽出面積の比較

\begin{tabular}{|ccc|}
\hline $\begin{array}{c}\text { UAV による空中写真 } \\
\text { 判読結果 }\left(\mathrm{m}^{2}\right)\end{array}$ & $\begin{array}{c}\text { 正規化植生指 } \\
\text { 標値差分抽出 }\left(\mathrm{m}^{2}\right)\end{array}$ & $\begin{array}{c}\text { 抽出(合致) } \\
\text { 面積 }\left(\mathrm{m}^{2}\right)\end{array}$ \\
\hline 488440.5 & 387734.5 & $373565.2(76 \%)$ \\
\hline
\end{tabular}

\section{5. おわりに}

ここでは観測後，準リアルタイムに観測データを入 手可能なLandsat-8/OLIによる画像情報とASTER/GDEM標 高情報から, 口永良部島の噴火に伴う, 火砕流の広がり 状況が画像判読調査から示された。 また，被災に伴う周 辺環境への影響が衛星データの持つマルチスペクトル情 報による正規化植生指標值によって被害傾向を把握する ことや噴煙や被雲による過抽出があるものの画像判読結 果とほぼ同様の被害域の傾向を抽出できた.このことは, 即応性が求めれる災害対応での利用可能性も示されたと 考えられる. 今後は衛星観測の優位性である周期的な情 報取得特性も生かしながら継続的モニタリングを実施す る予定である.
謝辞 : Landsat-8/OLI 画像データは米国地質調査所の提供 による. Aster Global DEM データは米国サウスダコタ州 Sioux Falls にある NASA/EOSDIS Land Processes Distributed Active Archive Center (LPDAAC) によって整備されている $\mathrm{WEB}^{15)}$ から検索され, 画像データプロダクトは NASAに よって提供された。また, ASTER GDEM は経済産業省 と NASA によるプロダクトである. 図-10 は（株）パス コによる口永良部島火山活動モニタリング 2015 年 6 月 4 日撮影画像斜め写真 ${ }^{16}$ を使用した。 .困-16,17,22 は国土 地理院の無人航空機（UAV）による口永良部島噴火後 の空中写真 (平成 27 年 9 月撮影) および写真判読結果 を使用した。

\section{参考文献}

1）福岡県管区気象台 火山監視・情報センター, 鹿児島県 地方気象台: 口永良部島の火山活動解説資料（平成 27 年 5 月），<http://www.jma-net.go.jp/fukuoka/jikazan /kinkyu/V20150529000150903000001505300824.pdf>, (入手 2015.6.10).

2) 国土地理院：口永良部島の火山活動に関する情報, $\succ$ http://www.gsi.go.jp/BOUSAI/h27-kuchinoerabu-index.html，（入 手 2015.6.25).

3) 豊田弘道, 田中總太郎, 杉村俊郎, 中山裕則 : 昭和61年 伊豆大島噴火に係るリモートセンシング，日本リモート センシング学会誌, Vol.6,No.4,pp.27-63.1986.

4) 中山裕則, 田中總太郎, 西川肇, 藤井寿生, 岩下圭之, 千葉達郎：SPOTデータによる雲仙火砕流モンタージュ画 像，日本リモートセンシング学会誌，Vol.11,No. 3,pp.43-47, 1991.

5) Urai M. : Volcano monitoring with Landsat TM short-wave infrared bands: the 1990-1994 eruption of Unzen Volcano, Japan, International Journal of Remote Sensing, Vol. 21, No. 5, pp. 861-872, 2000.

6) Marzano F.S., Lamantea M., Montopoli M., Herzog M.,Graf H., and Cimini D.: Microwave remote sensing of the 2011 Plinian eruption of the Grímsvötn Icelandic volcano, Remote Sensing of Environment, Vol. 129,pp. 168-184, 2013.

7) Kubanek J., Westerhaus M., Schenk A., Aisyah N.,Brotopuspito K.S., and Heck B.: Volumetric change quantification of the 2010 Merapi eruption using TanDEM-X In SAR, Remote Sensing of Environment, Vol. 164,pp. 16-25, 2015.

8) 山西亜希, 上條隆志, 恒川篤史, 樋口広芳 : 衛星リモー トセンシングによる伊豆諸島三宅島2000年噴火の植生被害 の把握, ランドスケープ研究, Vol. 66, No. 5, pp. 473-476, 2003.

9）菅野正人, 加藤正人 : 衛星データによる2000年有珠山噴火 の降灰と森林被害の把握, 日本リモートセンシング学会 誌, Vol.22,No. 1,pp. 89-95,2002.

10) 気象研究所 : 火山噴火予知連絡会拡大幹事会 (2015.8.21), ALOS-2/PALSAR-2SAR 干涉解析による口永良部島の地殻 変動について,

$<$ http://www.data.jma.go.jp/svd/vois/data/tokyo/STOCK/kaisetsu/CCP VE/shiryo/kakudai150821/9_mri_kuchinoerabu_SAR.pdfs，（入手 
2015.12.22)

11) Zhang Y.: Problems in the fusion of commercial high-resolution satellite as well as Landsat 7 images and initial solutions, In ISPRS, Geo Spatial Theory, Processing and Applications,Ottawa,Canada,Vol. 34, Part4, 2002.

12) Richter R., Schläpfer D. and Müller A.: An automatic atmospheric correction algorithm for visible /NIR imagery, International Journal of Remote Sensing,Vol. 27, No. 10, pp. 2077-2085, 2006.

13）産業技術総合研究所・地質調査総合センター：口永良部 島火山の噴火に関する情報 [2015年5月］, ‘https:/www. gsj.jp/hazards/volcano/kuchinoerabujima2015/index.html>，(入手 2015.6.25) .
14）国土地理院：口永良部島火山の噴火に関寸る情報, $<$ http://www.gsi.go.jp/BOUSAI/h27-kuchinoerabu-index.html»，人 手 2015.9.12).

15) LPDAAC : Routine ASTER Global Digital Elevation Model, $<\mathrm{https}$ ///pdaac.usgs.gov/dataset_discovery/aster/aster_products_table/ast $\mathrm{gtm}>，($ 入手2015.6.10)．

16) 株式会社パスコ：口永良部島火山活動モニタリング, $<$ http:// www.pasco.co.jp/disaster_info/150601〉，(入手2015. 6.20)

(2015.10.26受付)

\section{Immediate investigation of volcanic hazard of Kuchienorabu Island and influence on surrounding environment by using near real-time satellite images}

\section{Hideki HASHIBA and Masashi SONOBE}

A large-scale eruption occurred in Kagoshima, Kuchienorabu Island on May 29, 2015. This eruption released pyroclastic flow, which reached the shore areas. In this study, the disaster caused by this eruption was investigated using near real-time multi-spectral satellite images from Landsat-8/OLI, observed before and after the eruption, and ASTER/Global DEM data. These data were used for detailed image interpretation and three-dimensional indications of the extent of damage and the area covered by the pyroclastic flow. Furthermore, the characteristics of the distribution of damaged forest areas were obtained through NDVI analysis. From these investigations, the effectiveness of information from the near real-time remote sensing data in the evaluation of the volcanic disaster was assessed. 